\title{
Listeria monocytogenes (Lm)-LLO immunotherapies reduce the immunosuppressive activity of myeloid-derived suppressor cells and regulatory $T$ cells in the tumor microenvironment
}

\author{
Anu Wallecha*, Inga Malinina, Poonam Molli \\ From Society for Immunotherapy of Cancer 28th Annual Meeting \\ National Harbor, MD, USA. 8-10 November 2013
}

Myeloid-derived suppressor cells (MDSC) and regulatory $\mathrm{T}$ cells (Treg) are major components of the immune suppressive cells that potentially limit the effectiveness of an immunotherapy-based treatment. Both of these suppressive cell types have been shown to expand in tumor models and promote $\mathrm{T}$-cell dysfunction that in turn favors tumor progression. In preclinical studies using transplantable mouse models, we observed that live attenuated bioengineered Listeria monocytogenes (Lm)-LLO immunotherapies have an impact on the suppressive ability of MDSC and Treg in the tumor microenvironment (TME), resulting in a loss in the ability of these cells to suppress $\mathrm{T}$ cells. This alteration of immunosuppression in the TME was an inherent property of all Lm-LLO immunotherapies tested and was independent of the tumor model. The virtually total loss in the suppressive ability of these cells in the TME was linked to a decrease in the expression of arginase I in MDSC and IL-10 in Treg. We are further investigating if the MDSC are differentiated into functional macrophages that increase antigen presentation within the TME in order to stimulate T cell immunity. Overall, this study provides insight into a potentially novel mechanism of action of Lm-LLO immunotherapies that may contribute to therapeutic antitumor responses.

Published: 7 November 2013

Research and Development, Advaxis Inc., Princeton, NJ, USA
doi:10.1186/2051-1426-1-S1-018

Cite this article as: Wallecha et al:: Listeria monocytogenes (Lm)-LLO immunotherapies reduce the immunosuppressive activity of myeloid-derived suppressor cells and regulatory $T$ cells in the tumor microenvironment. Journal for ImmunoTherapy of Cancer 2013 1(Suppl 1):018.
Submit your next manuscript to BioMed Central and take full advantage of:

- Convenient online submission

- Thorough peer review

- No space constraints or color figure charges

- Immediate publication on acceptance

- Inclusion in PubMed, CAS, Scopus and Google Scholar

- Research which is freely available for redistribution

Submit your manuscript at www.biomedcentral.com/submit

(c) 2013 Wallecha et al; licensee BioMed Central Ltd. This is an Open Access article distributed under the terms of the Creative 